\title{
Enhancing Students' Proficiency in Writing Exposition Paragraph Through Collaboration
}

\author{
Umi Sholihah ${ }^{1}$, \\ *Widya Dharma University Klaten, Jl. Ki Hajar Dewantara, Klaten, \\ Central Java, Indonesia. Email: umisholihah84@gmail.com
}

Umi Sholihah is a lecturer at Widya Dharma University, Klaten. She received her master degree in English Education Pascasarjana, Sebelas Maret University Surakarta. Her research interests include English education, language and social, and the use of technology in English as Foreign Language teaching. She had conducted research about the use of some methods in improving English skills, and the analysis of English competences of some subjects. Her recent research is the analysis of English language skills of tourism actors in Klaten.

\author{
Ana Setyandari ${ }^{2}$, \\ *Widya Dharma University Klaten, Jl. Ki Hajar Dewantara, Klaten, \\ Central Java, Indonesia. Email:anasetyandari17@gmail.com
}

\begin{abstract}
This study aims at enhancing students' writing exposition paragraph through collaboration by utilizing Google Docs and peer-review technique. Based on the findings in preliminary research, students got difficulties in writing. The subject of this research is the fourth semester students of English Study Program of Widya Dharma University Klaten. Data showed from the pre-test, the students' skills in each writing aspects are still low, namely organization (62\%), content $(65 \%)$, syntax/grammar $(61 \%)$, mechanics $(57 \%)$, and vocabulary $(66 \%)$. The techniques of collecting the data in this study are observation, interview, questionnaire, and test. The technique of analyzing the data is using interactive model analysis from Miles \& Huberman for qualitative data and descriptive statistic for quantitative data. The results of the study show that there are significant improvement of students' writing exposition paragraph viewed from mean scores of pre-test $(63,1)$, cycle I $(68,35)$, cycle II $(73,2)$, and cycle III $(81,55)$. The findings also present that teaching writing through collaboration by using peer review technique using Google Docs can improve the students' analytical and critical thinking, self-confidence, and social relation; make students to be more active; and create meaningful learning of the class situation.
\end{abstract}

Keywords: writing, exposition paragraph, collaboration, Google Docs

\section{Introduction}

English language proficiency is important skills in order to be able to get information easily in global era. By mastering English language skills, namely listening, speaking, reading, and writing, there are many chances to compete not 
only in getting a good education, but also in getting a job. Since writing is a productive and expressive activity that need a good skill in using correct grammar and appropriate vocabularies, so that writing is considered as the most difficult skill among others English skills Rovimiyanti (2008), Pranata (2013), and Nasution \& Siregar (2013). According to Nurgiyantoro (2001) and Alwasilah (in Mamluah (2013), writing got perception as more difficult skill (43,22\%) than others because teaching writing often dominated grammar discussion and writing theories that give less chance for students to practice their writing. Moreover, Nurgiyantoro (2001) said that in Indonesia educational system, from elementary school to college only provide chance to practice writing skill $23.34 \%$ lower than reading skill $23.45 \%$. Those problems also found in Widya Dharma University Klaten. Based on pre-liminary study, English students of Widya Dharma University Klaten also had problems in mastering writing skill, especially eksposition paragraph. Students need to master exposition paragraph because exposition paragraph as basic for writing an academic writing. The students need more exercises in practicing their ability of writing. As writing activity is a continuing process from drafting, editing, composing, and reviewing, the students need time and review activities to make a good composition.

There are many studies conducted to improve students' writing skill by using various techniques and learning media, such as guided writing strategy (Handayani, Nyoman, \& Ratminingsih, 2013), CIRC (Irawadi, Martha, \& Wendra, 2015), diary (Ningrum \& Rita, 2013), and journal (Safriana, Said, \& Waris, 2013). Unfortunately, those studies still offer individual learning, have not asked students to work collaborative, though collaborative skill needed in preparing competitive workers in global era. As the answer of those learners' need, nowadays, various studies emphasized collaboration skills such as the studies conducted by (Sihite, 2014) and (Alwasilah, 2001) about improving writing skills using collaborative learning. One of collaborative learning strategy is by using peer-review technique. Peer-review technique believed can make students work collaboratively in active and unjoyful learning (Nasution \& Siregar, 2013; Kustati \& Suhardi, 2014).

Furthermore, technology development, which gives a lot of benefit for human in almost all aspects of their life, included in education forces teachers to be always active, creative, and innovative to create appropriate strategies to support learning goals. One of technology application in learning is the use of various network applications, which used individually by students even by their own smartphone. The use of network application is to support individual learning that known as student-centered. Network applications that used todays by students' own smartphone are such as online dictionary, email, Plagiarism Checker, Spellogram. Nowadays, there are some studies using technology in promoting learning goals are the usage of blog (Wahyu, 2010), Facebook (Marza \& Hafizh, 2013), and web (Asri, 2011; Togatorop, 2015). Unfortunately, those studies also focused on individual learning, have not asked students to work collaboratively. One of technology usage in promoting learning goals that create collaborative skill is Google Docs. Google docs believed improve students' collaborative skill and promote learning goals (Setyawan, et al. 2012; Cholifah, 2014; Pormes \& Utomo, 2015; Dharmawan, et al. 2015).

From the background above, the writer conducted the study in enhancing students' proficiency in writing exposition paragraph through collaboration. The 
collaboration learning in this study conducted through peer-review technique by using Google Docs application.

\section{Theoretical Underpinning}

Collaborative learning is a group of students doing a learning process. Barkley et al (in Nahdi, 2011) state that collaborate means cooperate. In collaborative learning, students work in pair or group to reach learning goals. According to Barkley, et al (in Nahdi, 2011), there are some characteristics in collaborative learning. The first is intentional design. Collaborative learning has intentional design in order to reach learning goal. The second is all groups' members always are active in completing the task. The third is a meaningful learning. Students really get knowledge and improve their ability.

According to Nelson (2000), collaborative learning in writing focuses on collaboration of problem solving process. Collaborative learning activity proved can improve students' ability significantly (Alwasilah, 2001; Sihire, 2014; and Togatorop, 2015). Nelson (2000) believes that students' experience in collaborative learning as basic in improving their communicative skill and create positive attitude in education and their future professional life. Collaboration in this study means peer collaboration in process of writing exposition paragraph through continuous writing, reading, and reviewing activity in form of discussion, question and answer, and giving comments which often known as peer review technique. Peer-review technique is a learning activity focused on learning writing. This technique is a collaborative technique which can make students more active in learning writing by working together with their friends to share ideas and suggestion of their work each other (Kustati \& Suhardi, 2014), and make students feel enjoy and be active in learning writing (Nasution \& Siregar, 2013). Peer-review also named peer-feedback, peer-response, or peer-editing in language teaching (Liu \& Hansen in Kustati \& Suhardi, 2014). Peer-review technique is the most important part of writing process because it makes use of drafting process and revision by pay attention writing process that consists of four elements those are planning, drafting, editing, and final revision Brown (2001: 348). By conducting peer-review, the students automatically conduct all those four elements of writing process itself. Applying peer-review technique in learning process can help students to know what their mistakes in writing so that they can revise and fix it.

In this study, collaborative learning through peer-review technique conducted by using Google Docs application. The use of Google Docs application in learning activity conducted in some studies, namely Cholifah (2014), Setyawan, et al (2014), Dharmawan et al (2015), and Pormes \& Utomo (2015). Dharmawan et al (2015) conclude that the use of Google Docs application in learning activity give some benefits. Those benefits are Google Docs is 1) more practical, effective, and efficient, 2) provide interaction between teacher and students anytime by online, 3) can monitor students even in holiday, 4) can be used to discuss material of learning, 5) can monitor students in real time when group working, 6) can finish the assignment in time.

Peer-review technique by utilizing Google Docs application in this study focuses on writing exposition paragraph. Students need to master exposition paragraph because exposition paragraph as basic for writing an academic writing. 
An exposition is a piece of text that presents one side of an issue to persuade the reader or listener by presenting one side of an argument, that is, the case or the case against. According to Alwasilah (2007: 51), an exposition paragraph is a paragraph that contains an explanation of something that intends to inform and aims to explain something to the reader. Widya (1992), Semi (2003), and Suparno (in Manullang (2012) state that an exposition is a text that aims to convey ideas and information in the form of facts or results of thought whose main purpose is to notify, peel, decipher, or explain something. Semi (in Manullang, 2012) adds exposition as 1) some writings that provide understanding and knowledge; 2) answer questions about what, why, when, and so on; 3) delivered openly; 4) using neutral, impartial, and imposing the attitude of the writer towards the reader. Through the production of exposition text, the author is accustomed to conceptualizing themes, putting them in a framework, writing them as whole essays, and communicating them.

In English learning, exposition paragraph has some characteristics based on its social function, generic/schematic structure, and language feature as followings:

a. Social function

Is a factual text that is used to express the opinion or point of view of the author, for examples: essay, letter to the editor.

b. Generic/schematic structure

The composition of the exposition paragraph consists of thesis, arguments, reiteration/restatement of thesis.

c. Language features

Language features of exposition text are:

- Focusing on people or things in general

- Using simple present tense

- Using temporal conjunction relations

- Using material, relational, and mental processes

(Metropolitan East Disadvantaged Schools Program, 1989)

\section{Methodology}

This study is classroom action consists of three circles, which each circle consists of two meetings for applying technique and one meeting for post-test. Classroom action research conducted through four stages: planning, acting, observing, and reflecting (Arikunto, 2006: 16). The subject of this study is forth semester of English students of Widya Dharma University Klaten. Data consist of qualitative data from observation, interview, questionnaire, and documents; and quantitative data from the results of pre-test and post-test of each circle. In analyzing non - numerical data or qualitative data, the researcher made use of interactive model proposed by Miles \& Huberman (1984: 21 - 23), and quantitative data analyze by using descriptive statistic to get the mean score. Analytical scoring rubrics used to get score of each aspect of writing. 

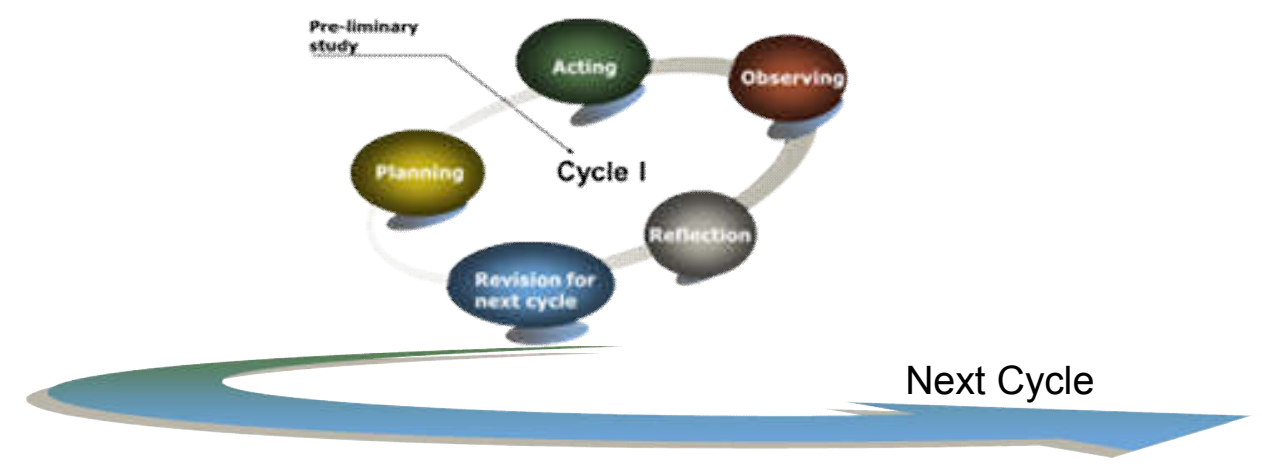

Figure 1 Classroom Action Research Model modified from Arikunto (2006: 16)

\section{Discussion}

This study applying peer-review technique by using Google Docs in teaching writing through the following procedures:

1) Students asked to make Google account.

2) Students asked to install Google Docs application in their own laptop or hand phone.

3) Teacher shows an example of Google Suite for Education to give brief understanding to the students how to use and what benefits of Google suite for education, especially Google Docs.

4) Students notified about topic discussed, writing genre based, namely expository paragraph.

5) Students explained it social function, generic structure, and language features.

6) Students asked to make a group and compose an expository paragraph.

7) Students asked to give their ideas, comments, and suggestion each other to others work. In this step is peer-review technique occured.

8) Before class ended, students asked to share their work by inviting others in Google Docs to continue their peer-review activity even not in class.

9) In the next meeting, students asked to present their work in front of the class, show their result of peer-review activities by Google Docs.

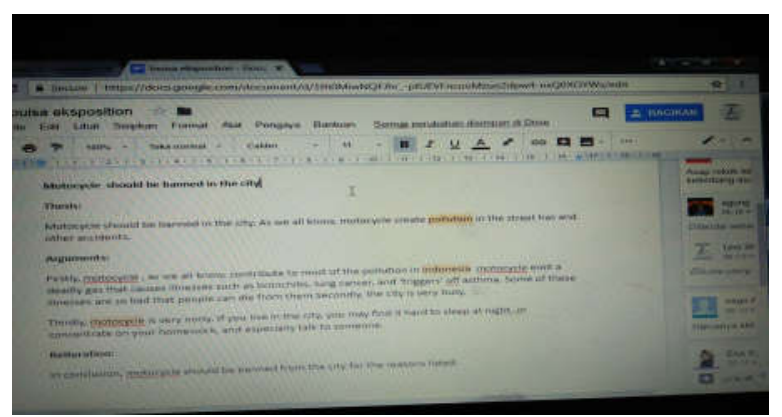

Picture 2 Collaboration Activity in Composing Exposition Paragrap by Using Google Docs Application

The results of the study show that peer-review technique by using Google Docs application is easy with efficient of time to improve students' writing skill 
of expository paragraph, improve students skill of collaboration, create meaningful learning activity, increase students' participation in writing class, make students more active and confident, improve students' critical thinking.

Quantitative data show that there are significant improvements of students' writing skill, in which score of pre-test (63.1), circle I (68.35), circle II (73.2), and circle III (81.55).

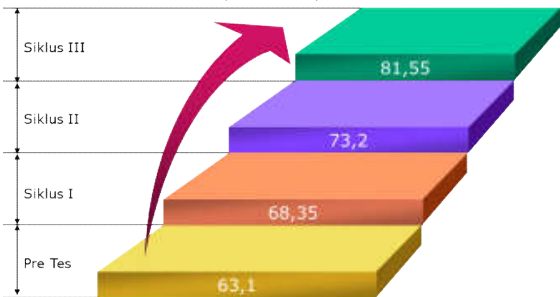

Picture 3 The Significant Improvements of Students' Proficiency in Writing Exposition Paragraph

The mean score of each aspects of writing also improved which explained in the following table.

Table 1 The Improvement of Mean Score in Each Aspects of Writing

\begin{tabular}{|c|c|c|c|c|}
\hline Writing Aspects & Pre - Test & Cycle 1 & Cycle 2 & Cycle 3 \\
\hline Organization & 12,4 & 13,75 & 14,75 & 16,45 \\
\hline Content & 19,5 & 20,25 & 21,7 & 25 \\
\hline Syntax / & & & & \\
Grammar & 15,25 & 16,75 & 18,25 & 20,25 \\
\hline Mechanics & 2,85 & 3,5 & 3,5 & 3,95 \\
\hline Vocabulary & 13,1 & 14,1 & 15 & 15,9 \\
\hline
\end{tabular}

Moreover, score percentage of each aspects of writing also increased. In organization aspect, the score percentage in pre-test is $62 \%$, Cycle 1 is $69 \%$, Cycle 2 is $74 \%$, and Cycle 3 is $82 \%$. In content aspect, the score percentage in pre-test is $65 \%$, Cycle 1 is $68 \%$, Cycle 2 is $72 \%$, and Cycle 3 is $83 \%$. In syntax/grammar aspect, the score percentage in pre-test is $61 \%$, Cycle 1 is $67 \%$, Cycle 2 is $73 \%$, and Cycle 3 is $81 \%$. In mechanics aspect, the score percentage in pre-test is $57 \%$, Cycle 1 is $70 \%$, Cycle 2 is $70 \%$, and Cycle 3 is $79 \%$. In vocabulary aspect, the score percentage in pre-test is $66 \%$, Cycle 1 is $71 \%$, Cycle 2 is $75 \%$, and Cycle 3 is $80 \%$.

Table 2 Percentage of Each Aspect of Writing

\begin{tabular}{|c|c|c|c|c|}
\hline $\begin{array}{c}\text { Writing } \\
\text { Aspects }\end{array}$ & Pre - Test & Cycle 1 & Cycle 2 & Cycle 3 \\
\hline Organization & $62 \%$ & $69 \%$ & $74 \%$ & $82 \%$ \\
\hline Content & $65 \%$ & $68 \%$ & $72 \%$ & $83 \%$ \\
\hline $\begin{array}{c}\text { Syntax / } \\
\text { Grammar }\end{array}$ & $61 \%$ & $67 \%$ & $73 \%$ & $81 \%$ \\
\hline Mechanics & $57 \%$ & $70 \%$ & $70 \%$ & $79 \%$ \\
\hline Vocabulary & $66 \%$ & $71 \%$ & $75 \%$ & $80 \%$ \\
\hline
\end{tabular}


Collaborative teaching using peer-review technique in writing activity by using Google Docs application have some advantages as described in the following picture.

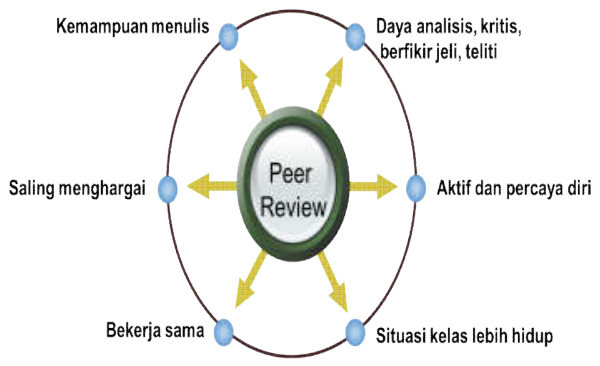

\section{Picture 4 Some Advantages of Collaborative Teaching in Writing Activity}

The above picture explained below.

a. Train students to think critically and be careful in reviewing others' writing so that automatically can improve their own writing skill. It is in line with Hansen \& Liu in Kustati \& Suhardi (2014) that claim peer-review technique makes students have critical thinking because give chances to the students to find out source of information while writing process from others' critic, comments, and suggestions.

b. Improve students' collaborative proficiency to face global era in $21^{\text {st }}$ century. Utilizing of Google Docs application forces students to collaborate each other so that increase students' social relationship, cooperation, and make them appreciate each other. Collaboration learning focusses on problem solving by thinking together that effectively empower students' writing profeciency (Hadiyanto \& Sundari, 2011), give chances for students who are more proficient in writing (that sometimes undetected and less challenged in writing activity which focused on theories and grammar discussion) to play a role as reviewers to teach and share their knowledge to others (Nelson, 2000).

c. Motivate students to be active in completing their writing tasks. Group working makes every students participate, be serious and responsible in doing the tasks. Tasks are supposed to be familiar to the students so they are more likely to be engaged which is further motivate them in learning the target language (Willis in Sholihah, 2011). Students' participation improved because the students find that the classroom learning related to this objective and helps them to achieve this objective with increasing success.

d. Create meaningful classroom activity. Collaborative learning creates meaningful learning that makes students be seriously and really give attention in learning process. This activity is effective and interesting because gives students many chances to use language optimally to communicate and discuss the given tasks (Harmer in Hadiyanto \& Sundari, 2011).

e. Make students enjoy and active in writing process. Nasution \& Siregar (2013) state that peer-review technique in collaborative learning make students enjoy and active in writing process.

f. Sharpen students' analysis so that can be used in other fields of study, such as in teenager's scientific paper (Dharmawan, et al, 2015), 


\section{Conclusion}

The conclusions of the study are peer-review technique in collaborative learning by using Google Docs sharpen students' analysis so that train students to think carefully and critically when reviewing others' work that automaticaly improve their writing skill. Futhermore, collabotive learning also trains students have collaborative and cooperative proficiency to compete in global era. Collaborative learning through peer-review by using Google Docs application is proven can improve students' writing ability so that can applied in other fields of study.

\section{References}

A Brief Introduction to Genre. 1989. Metropolitan East Disadvantaged School Program.

Alwasilah, A. Chaedar. (2001). Empowering College Student Writers Through Collaboration. Journal Teflin Vol XII, No. 1 February (2001). Hal. 1-13.

Arikunto, Suharsimi. 2006. Prosedur Penelitian Suatu Pendekatan Praktik. Jakarta: PT Rineka Cipta.

Asri, A. N. (2011). Using Web Folio to Improve Student's Writing Skills. Jurnal Ilmu Pendidikan, 17(5), 361-367.

Brown, Douglas H. 2001. Teaching by Principles: An interactive approach to language pedagogy, second edition.

Cholifah, Maria. (2014). Teaching Writing to Build Students' Character by Using Google Docs. Jurnal Inspirasi, Vol 4, No 1 hal. 438-445.

Dharmawan, Ramona, Rupiasih, \& Nilakusmawati. (2015). Pemanfaatan Aplikasi Google Docs Sebagai Media Pembinaan Karya Ilmiah Remaja. Fakultas MIPA Universitas Udayana. Prosiding Seminar Nasional Teknologi Informasi dan Aplikasinya (SNATIA) hal. 45-48.

Hadiyanto, \& Sundari, W. (2011). The Effectiveness of Student Grouping In Endorsing English Writing Skill Mastery. Lensa, 1(1), 51-56.

Handayani, A A Komang, Dantes, Nyoman, Ratminingsih, Ni Made. (2013) The Effect of Guided Writing Strategy and Students' Achievement Motivation on Students' Writing Competency. e-Journal Program Pascasarjana Universitas Pendidikan Ganesha, Program Studi Pendidikan Bahasa Inggris, Vol 1.

Irawadi, Made Hela; Martha, I Nengah; \& Wendra, I Wayan. (2015). Penerapan Model Pembelajaran Cooperative Integrated Reading and Composition (CIRC) untuk Meningkatkan Hasil Belajar Siswa dalam Menulis Karya Ilmiah di Kelas XII AP I SMK Negeri 1 Seririt. e-Journal Universitas Pendidikan Ganesha, Jurusan Pendidikan Bahasa dan Sastra Indonesia, Vol 3 No 1.

Kustati \& Yuhardi, The Effect of the Peer-Review Technique on Studentse Writing Ability. STUDIES IN ENGLISH LANGUAGE AND EDUCATION, Volume 1, Number 2, September 2014. Hal. 71-81.

Mamluah, Khidmatul. 2013. Penerapan Model Pembelajaran Assurance, Relevance, Interest, Assesment dan Satisfaction (ARIAS) dalam Pembelajaran Menulis Puisi. Bandung: Universitas Indonesia 
Manullang, Lili Feranti. (2012). Meningkatkan Kemampuan Menulis Paragraf Eksposisi dengan Model Pembelajaran Konstruktif. Jurnal Sasindo Vol 1. No. 2 (2012). Hal. 1-13.

Marza, L., \& Hafizh, M. (2013). Teaching Writing Recount Text to Junior HighSchool Students by Using Facebook Peer-Comment. Journal of English Language Teaching, 1(2), 683-692.

Miles, Mathew \& Huberman, A. Michael. 1984. A Qualitative Data Analysis. Sage Publication, Inc.

Nahdi, Muhammad. (2011). Improving Students' Writing Ability by Using Peer Editing Technique.

Nasution, N.S.R., \& Siregar, Masitowarni (2013). Improving Students' Writing Recount Achievement Through Peer Review Technique. GENRE Journal of Applied Linguistics of FBS Unimed, Vol 2. No 1 (2013).

Nelson, Stephanie. (2000). Teaching Collaborative Writing and Peer Review Techniques to Engineering and Technology Undergraduates. Frontier in Education Conference, 2000. FIE 2000. 30th Annual. Diambil dari: ieeexplore.ieee.org

Ningrum, V., \& Rita, F. (2013). Improving Writing Skill in Writing Recount Text Through Diary Writing. Journal of English Language Teaching Society (ELTS), 1(1), 1-13.

Nurgiyantoro, Burhan. 2001. Menulis secara Populer. Jakarta: Pustaka Jaya.

Pranata, Alit Kusuma. (2013). Penggunaan Teknik 3-P untuk Meningkatkan Kemampuan Menulis Berita Berbasis 5W $+1 \mathrm{H}$ Siswa Kelas VIII A SMP Negeri 7 Singaraja. Jurnal Jurusan Pendidikan Bahasa dan Sastra Indonesia Vol 1, No. 1 (2013).

Rovimiyanti. (2008). Kemampuan Menulis Paragraf Siswa Kelas X SMK Taruna Bhakti Malang Tahun Ajaran 2007/2008. Jurnal Artikulasi Vol 5, No. 1 (2008): Februari.Hal. 230-242.

Safriana, Said, M. M., \& Waris, A. (2013). Developing Writing Skill through Journals. Journal of English Language Teaching Society (ELTS), 1(1), 1-10.

Setyawan, Gelegar Yudha, Martono, \& Rochsantiningsih, Dewi. (2014). Optimizing Google Docs to Improve Students' Writing Skill of Descriptive Text. English Education, Vol 2, No 2 hal. 233-243. http://www.jurnal.fkip.uns.ac.id/index.php/bhs inggris/article/view/7947/5790

Sholihah, Umi. (2011). "Improving Students' Writing Ability Using Task - Based Language Teaching (TBLT) (A Classroom Action Research at the Students of Class X TKJ 1 SMKN 2 Sragen in the 2010/2011 Academic Year)". https://digilib.uns.ac.id.

Sihite, Pitra. (2014). Pengaruh Model Pembelajaran Kolaboratif (Collaborative Learning) terhadap Kemampuan Menulis Teks Eksposisi Siswa Kelas X SMA Negeri 1 Balige Tahun Pembelajaran 2013/2014. Jurnal Bahasa Universitas Negeri Medan Vol 3, No 3.

Togatorop, Ericson. (2015). Teaching Writing with a Web Based Collaborative Learning. International Journal of Economics and Financial Issues, 2015, 5 (Special Issue) 247-256.

Pormes R. \& Utomo, W. H. (2015). Analisis Perbandingan Cloud Document pada EyeOS dan Google Docs. Jurnal Sistem Komputer, Vol 5, No 1 hal 19-21 (2015): Mei 2015. http://docs.google.com/ 
Wahyu, Hedi. (2010). Meningkatkan Kemampuan Menulis Eksposisi dengan Menggunakan Media Blog. Jurusan Pendidikan Bahasa dan Sastra Indonesia. FPBS, Universitas Pendidikan Indonesia. 